\title{
Structural insights into PROTAC-mediated degradation of Bcl-xL
}

Chun-wa Chung ${ }^{1, *}$, Han Dai ${ }^{3}$, Esther Fernandez ${ }^{2}$, Christopher P. Tinworth ${ }^{2}$, Ian Churcher ${ }^{2}$, Jenni Cryan², Jane Denyer², John D. Harling², Agnieszka Konopacka², Markus A. Queisser², Christopher J. Tame ${ }^{2}$, Gillian Watt ${ }^{2}$, Fan Jiang ${ }^{5}$, Dongming Qian ${ }^{5}$, Andrew B. Benowitz ${ }^{2}$

${ }^{1}$ Protein, Cellular \& Structural Sciences, GlaxoSmithKline, Gunnels Wood Road, Stevenage, SG1 2NY, UK; ${ }^{2}$ Protein Degradation Group, GlaxoSmithKline, Gunnels Wood Road, Stevenage, SG1 2NY, UK; ${ }^{3}$ Protein Degradation Group, GlaxoSmithKline, 1250 South Collegeville Road, Collegeville, PA 19426, USA; ${ }^{5}$ Viva Biotech Ltd., 334 Aidisheng Rd., Zhangjiang High-tech Park, Shanghai 201203, China.

* Correspondence should be addressed to Chun-wa Chung: chun-wa.h.chung@gsk.com

Keywords: Bcl-xL, Bcl-2, mitochondrial membrane protein, PROTAC, ternary complex 


\section{Supplementary Information}

\section{Contents}

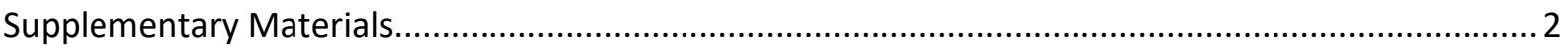

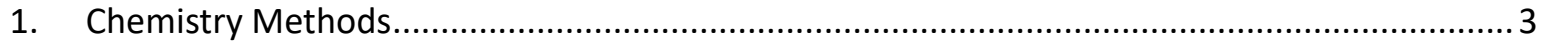

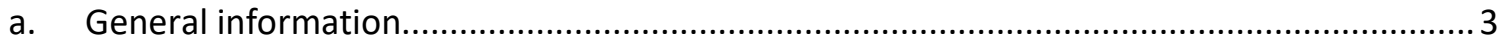

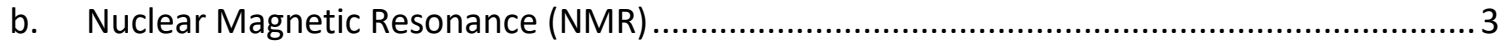

c. Liquid Chromatography Mass Spectroscopy (LCMS) ….......................................... 3

d. High Resolution Mass Spectroscopy (HRMS) ................................................... 4

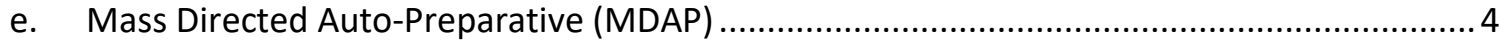

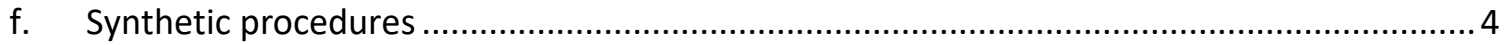

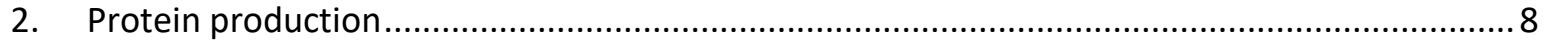

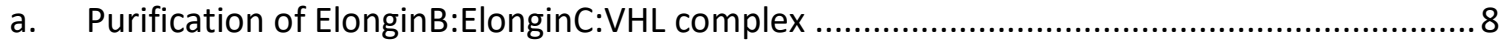

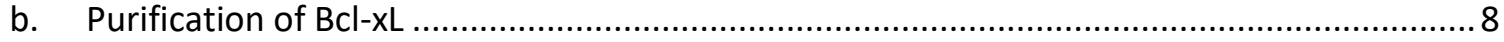

3. Biochemical, Cellular and Biophysics methods ........................................................ 8

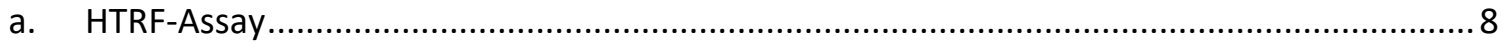

b. Bcl-xL protein quantification by western blotting ............................................... 9

c. Surface Plasmon Resonance affinity measurements ............................................... 9

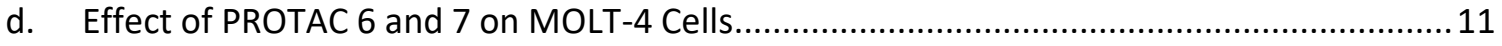

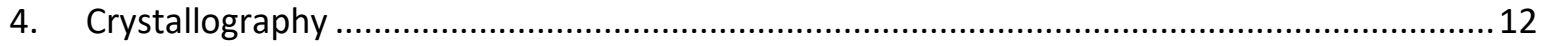

a. Purification of the ElonginB:ElonginC:VHL/PROTAC 6/Bcl-xL complex ............................ 12

b. Crystallization of the ElonginB:ElonginC:VHL/PROTAC 6/Bcl-xL complex ........................ 12

c. Structure determination of the ElonginB:ElonginC:VHL/PROTAC 6/Bcl-xL complex ........... 12

d. Table of Data collection and refinement statistics .............................................. 12

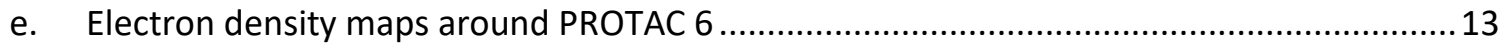

f. Comparison of $\mathrm{VHL}$ and $\mathrm{Bcl}-\mathrm{xL}$ binding in binary and ternary complexes........................ 14

g. Breakdown of buried surface areas in the ternary complexes ligase:ligand:target........... 15

h. Comparison of interface residues in ternary versus binary complexes...........................15

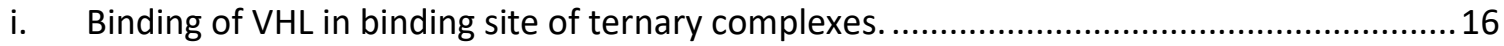

j. $\quad$ Alignment of $\mathrm{Bcl}-2$ to consider the effect on the $\mathrm{Bcl}-\mathrm{xL} / \mathrm{VHL}$ interface...........................16

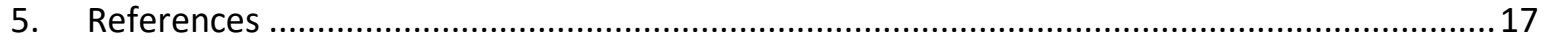




\section{Chemistry Methods}

\section{a. General information}

All temperatures are in ${ }^{\circ} \mathrm{C}$.

\section{b. Nuclear Magnetic Resonance (NMR)}

NMR spectra were recorded using a Bruker DPX400, DPX500, AV400, or AVIII600 (with cryoprobe). Chemical shifts $(\delta)$ are reported in parts per million $(\mathrm{ppm})$ relative to tetramethylsilane and coupling constants $(\mathrm{J})$ in $\mathrm{Hz}$. The following abbreviations are used for multiplicities: $\mathrm{s}=$ singlet; $\mathrm{br} . \mathrm{s}=$ broad singlet; $d$ = doublet; $t$ = triplet; $q$ = quartet; $s p t=$ septet; $m$ = multiplet; $d d=$ doublet of doublets. If not specifically stated, the NMR experiments were run at $30^{\circ} \mathrm{C}$.

\section{c. Liquid Chromatography Mass Spectroscopy (LCMS)}

\section{i. LCMS Method A}

The analysis was conducted on an Acquity UPLC BEH C18 column $(50 \mathrm{~mm} \times 2.1 \mathrm{~mm}$ internal diameter $1.7 \mu \mathrm{m}$ packing diameter) at $40^{\circ} \mathrm{C}$.

The solvents employed were:

$\mathrm{A}=0.1 \% \mathrm{v} / \mathrm{v}$ solution of formic acid in water.

$\mathrm{B}=0.1 \% \mathrm{v} / \mathrm{v}$ solution of formic acid in acetonitrile.

The gradient employed was as follows:

\begin{tabular}{|l|l|l|l|}
\hline Time (min) & Flow rate (mL/min) & \% A & \% B \\
\hline \hline 0 & 1 & 97 & 3 \\
\hline 1.5 & 1 & 5 & 95 \\
\hline 1.9 & 1 & 5 & 95 \\
\hline 2.0 & 1 & 97 & 3 \\
\hline
\end{tabular}

The UV detection was an averaged signal from wavelength of $210 \mathrm{~nm}$ to $350 \mathrm{~nm}$ and mass spectra were recorded on a Waters ZQ mass spectrometer using alternate-scan positive and negative mode electrospray ionisation (ES +ve and ES -ve).

\section{ii. LCMS Method B}

The analysis was conducted on an XBridge C18 column ( $50 \mathrm{~mm} \times 4.6 \mathrm{~mm}$ internal diameter $3.5 \mu \mathrm{m}$ packing diameter) at $30^{\circ} \mathrm{C}$. The solvents employed were:

$\mathrm{A}=10 \mathrm{mM}$ ammonium bicarbonate in water adjusted to $\mathrm{pH} 10$ with ammonia solution

$B=$ acetonitrile

The typical gradient employed was as follows:

\begin{tabular}{|l|l|l|l|}
\hline Time & Flow rate & $\%$ A & $\%$ B \\
\hline \hline
\end{tabular}




\begin{tabular}{|l|l|l|l|}
\hline \hline 0 & 1 & 97 & 3 \\
\hline 0.05 & 1 & 97 & 3 \\
\hline 1.50 & 1 & 5 & 95 \\
\hline 1.90 & 1 & 5 & 95 \\
\hline 2.00 & 1 & 97 & 3 \\
\hline
\end{tabular}

The UV detection was an averaged signal from wavelength of $210 \mathrm{~nm}$ to $350 \mathrm{~nm}$ and mass spectra were recorded on a Waters ZQ mass spectrometer using alternate-scan positive and negative mode electrospray ionisation (ES +ve and ES -ve).

\section{d. High Resolution Mass Spectroscopy (HRMS)}

ESI (+) high resolution mass spectra were obtained on a Waters XEVO G2-XS QTof hybrid quadrupole time-of-flight mass spectrometer, equipped with a Z-spray interface, over a mass range of $100-1500$ Da. The elemental composition was calculated using MassLynx v4.1 for the $[\mathrm{M}+\mathrm{H}]^{+}$and the mass error quoted as ppm.

\section{e. Mass Directed Auto-Preparative HPLC (MDAP)}

"Mass directed automated preparative HPLC" (MDAP) was conducted on a system such as a Waters FractionLynx system comprising of a Waters 600 pump with extended pump heads, Waters 2700 autosampler, Waters 996 diode array and Gilson 202 fraction collector on an XBridge C18 column (100 $\mathrm{mm} \times 30 \mathrm{~mm}$ i.d. $5 \mu \mathrm{m}$ packing diameter) at ambient temperature, eluting with $10 \mathrm{mM}$ ammonium bicarbonate in water adjusted to $\mathrm{pH} 10$ with ammonia solution (solvent $\mathrm{A}$ ) and acetonitrile (solvent $\mathrm{B}$ ) using the appropriate elution gradient. The UV detection was a summed signal from wavelength of $210 \mathrm{~nm}$ to $350 \mathrm{~nm}$. The mass spectra were recorded on a Waters ZQ spectrometer using electrospray positive and negative mode (ES + ve and ES -ve). The software used was MassLynx 3.5 with OpenLynx and FractionLynx option or using equivalent alternative systems. Similar systems using Sunfire C18 columns and gradient of solvents such as $0.1 \%$ formic acid in water (solvent $A$ ) and acetonitrile (solvent B) were also employed.

\section{f. Synthetic procedures}

\section{i. Scheme S1}
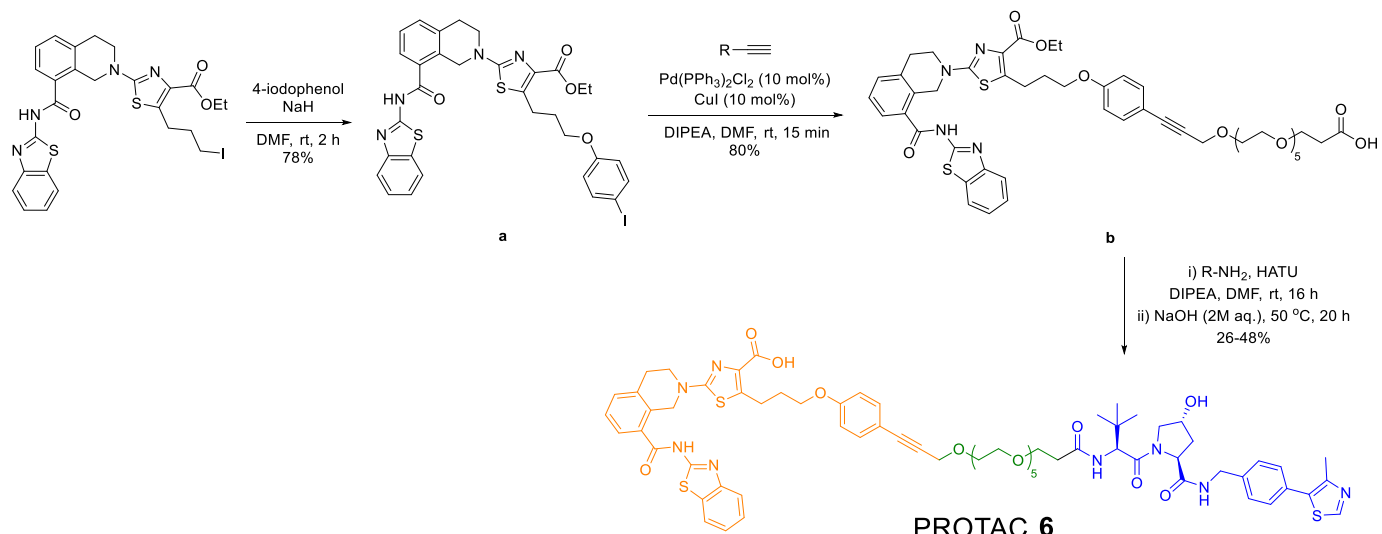

PROTAC 6

PROTAC 7 (ent-PROTAC 6) 
Ethyl 2-(8-(benzo[d]thiazol-2-ylcarbamoyl)-3,4-dihydroisoquinolin-2(1H)-yl)-5-(3-iodopropyl)thiazole4-carboxylate and 2-(8-(benzo[d]thiazol-2-ylcarbamoyl)-3,4-dihydroisoquinolin-2(1H)-yl)-5-(3iodopropyl)thiazole-4-carboxylate were prepared as described by Tao et al. ${ }^{1}(2 S, 4 R)-1-((S)$-2-amino3,3-dimethylbutanoyl)-4-hydroxy- $N$-(4-(4-methylthiazol-5-yl)benzyl)pyrrolidine-2-carboxamide and (2R,4S)-1-((R)-2-amino-3,3-dimethylbutanoyl)-4-hydroxy- $N$-(4-(4-methylthiazol-5-yl)benzyl)

pyrrolidine-2-carboxamide were prepared as described by Ciulli et al. ${ }^{2}(2 S, 4 R)-1-((S)-2$-amino-3,3dimethylbutanoyl)-4-hydroxy- $N$-((S)-1-(4-(4-methylthiazol-5-yl)phenyl)ethyl)pyrrolidine-2-

carboxamide dihydrochloride and (2R,4S)-1-((R)-2-amino-3,3-dimethylbutanoyl)-4-hydroxy- $N-((R)-1-$ (4-(4-methylthiazol-5-yl)phenyl)ethyl)pyrrolidine-2-carboxamide dihydrochloride were prepared as described by Raina et al. ${ }^{3}$

i. Ethyl 2-(8-(benzo[d]thiazol-2-ylcarbamoyl)-3,4-dihydroisoquinolin-2(1H)-yl)-5-(3-(4iodophenoxy)propyl)thiazole-4-carboxylate (a)

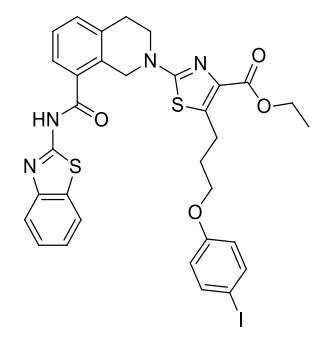

To a stirred solution of 4-iodophenol (441 mg, $2.01 \mathrm{mmol})$ in DMF (10 mL) was added sodium hydride $(60 \% \mathrm{w} / \mathrm{w}, 107 \mathrm{mg}, 2.67 \mathrm{mmol})$, then the slurry stirred at $\mathrm{rt}$ for $15 \mathrm{~min}$ after which time the mixture had homogenised. The mixture was cooled to $0{ }^{\circ} \mathrm{C}$, then ethyl 2-(8-(benzo[d]thiazol-2-ylcarbamoyl)3,4-dihydroisoquinolin-2(1H)-yl)-5-(3-iodopropyl)thiazole-4-carboxylate (940 mg, $1.34 \mathrm{mmol}$ ) was added and the mixture was stirred at $\mathrm{rt}$ for $2 \mathrm{~h}$. The mixture was quenched with water, then the mixture diluted with EtOAc and the $\mathrm{pH}$ adjusted to $\sim 2$ with $\mathrm{HCl}(2 \mathrm{M}$ aq.). The aqueous layer was backextracted with EtOAc $(50 \mathrm{~mL})$, then the organic layers were combined, washed with brine, dried using a hydrophobic frit and evaporated in vacuo. The sample was loaded in DMSO and purified by reverse phase (C18) chromatography using a 70-95\% acetonitrile-water $(0.1 \%$ ammonium bicarbonate modifier) gradient over $12 \mathrm{CV}$. The appropriate fractions were combined, then acetonitrile removed in vacuo, then the aqueous slurry extracted with EtOAc $(2 \times 150 \mathrm{~mL})$. The organic layers were combined and evaporated in vacuo to give the required product ( $756 \mathrm{mg}, 78 \%$ yield) as a beige solid.

${ }^{1} \mathrm{H}$ NMR (400 MHz, DMSO-d d $\delta 12.83$ (br. s., $\left.1 \mathrm{H}\right), 8.04$ (d, $\left.J=7.6 \mathrm{~Hz}, 1 \mathrm{H}\right), 7.80$ (d, $\left.J=7.8 \mathrm{~Hz}, 1 \mathrm{H}\right), 7.67$ $(\mathrm{d}, J=7.1 \mathrm{~Hz}, 1 \mathrm{H}), 7.56(\mathrm{~d}, J=8.8 \mathrm{~Hz}, 2 \mathrm{H}), 7.52-7.43(\mathrm{~m}, 2 \mathrm{H}), 7.43-7.32(\mathrm{~m}, 2 \mathrm{H}), 6.76(\mathrm{~d}, J=9.0 \mathrm{~Hz}, 2 \mathrm{H})$, $4.83(\mathrm{~s}, 2 \mathrm{H}), 4.16(\mathrm{q}, J=7.1 \mathrm{~Hz}, 2 \mathrm{H}), 3.96(\mathrm{t}, J=6.1 \mathrm{~Hz}, 2 \mathrm{H}), 3.72(\mathrm{t}, J=6.0 \mathrm{~Hz}, 2 \mathrm{H}), 3.15(\mathrm{t}, J=7.6 \mathrm{~Hz}$, 2H), $3.04(\mathrm{t}, J=5.9 \mathrm{~Hz}, 2 \mathrm{H}), 2.04-1.94(\mathrm{~m}, 2 \mathrm{H}), 1.18(\mathrm{t}, J=7.1 \mathrm{~Hz}, 3 \mathrm{H}$ ). LCMS (Method B) m/z 724.1 (M $+\mathrm{H})^{+}$Rt $1.62 \min (>95 \%$ pure). 


\section{ii. 22-(4-(3-(2-(8-(Benzo[d]thiazol-2-ylcarbamoyl)-3,4-dihydroisoquinolin-2(1H)-yl)-4- (ethoxycarbonyl)thiazol-5-yl)propoxy)phenyl)-4,7,10,13,16,19-hexaoxadocos-21- ynoic acid (b)}

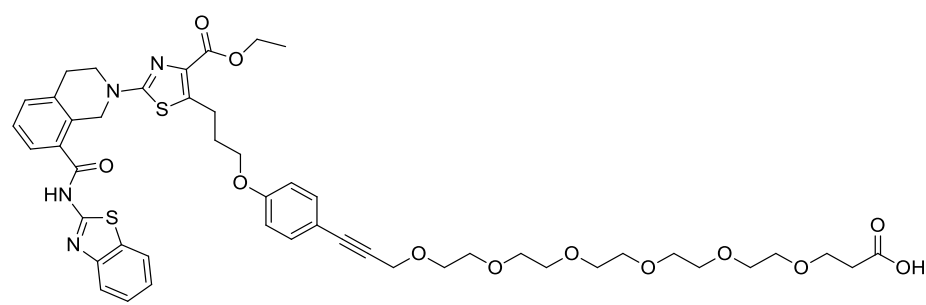

To a degassed solution of ethyl 2-(8-(benzo[d]thiazol-2-ylcarbamoyl)-3,4-dihydroisoquinolin-2(1H)-yl)5-(3-(4-iodophenoxy)propyl)thiazole-4-carboxylate (213 $\mathrm{mg}, 0.235 \mathrm{mmol}), \quad 4,7,10,13,16,19$ hexaoxadocos-21-yn-1-oic acid (123 mg, $0.353 \mathrm{mmol}$ ) and DIPEA (0.205 mL, $1.18 \mathrm{mmol})$ in DMF ( $2 \mathrm{~mL})$ was added bis(triphenylphosphine)palladium(II) chloride (16.5 mg, $0.0240 \mathrm{mmol}$ ) and copper(I) iodide (4.5 $\mathrm{mg}, 0.024 \mathrm{mmol}$ ) then the mixture stirred at $\mathrm{rt}$ for $15 \mathrm{~min}$. The mixture was diluted with EtOAc $(20 \mathrm{~mL})$, water $(15 \mathrm{~mL})$, and citric acid $(5 \%$ aq., $5 \mathrm{~mL})$, then the phases were separated. The aqueous layer was back-extracted with EtOAc $(2 \times 10 \mathrm{~mL})$, then the organic layers were combined, dried using a hydrophobic frit and evaporated in vacuo. The residue was dissolved in DMSO and purified by reverse phase ( $\mathrm{C} 18$ ) chromatography using a 50-95\% acetonitrile-water (0.1\% ammonium bicarbonate modifier gradient) over $12 \mathrm{CV}$. The appropriate fractions were combined and acetonitrile removed in vacuo, then the $\mathrm{pH}$ adjusted to $\sim 3$ with $\mathrm{HCl}$ (2M aq.), then and the aqueous slurry extracted with EtOAc $(3 \times 40 \mathrm{~mL})$. The organic layers were combined and evaporated in vacuo to give the required product (177 $\mathrm{mg}, 80 \%$ yield) as an orange gum.

${ }^{1} \mathrm{H}$ NMR $\left(400 \mathrm{MHz}, \mathrm{DMSO}-\mathrm{d}_{6}\right) \delta 8.03(\mathrm{~d}, J=7.3 \mathrm{~Hz}, 1 \mathrm{H}), 7.79(\mathrm{~d}, J=8.1 \mathrm{~Hz}, 1 \mathrm{H}), 7.66(\mathrm{~d}, J=6.6 \mathrm{~Hz}, 1 \mathrm{H})$, 7.50-7.43 (m, 2H), 7.42-7.32 (m, 4H), $6.90(\mathrm{~d}, J=8.8 \mathrm{~Hz}, 2 \mathrm{H}), 4.83(\mathrm{~s}, 2 \mathrm{H}), 4.35(\mathrm{~s}, 2 \mathrm{H}), 4.15(\mathrm{q}, J=7.1$ $\mathrm{Hz}, 2 \mathrm{H}), 3.99(\mathrm{t}, J=6.1 \mathrm{~Hz}, 2 \mathrm{H}), 3.71(\mathrm{t}, J=6.0 \mathrm{~Hz}, 2 \mathrm{H}), 3.63-3.54(\mathrm{~m}, 7 \mathrm{H}), 3.53-3.46(\mathrm{~m}, 17 \mathrm{H}), 3.16(\mathrm{t}, J$ $=7.5 \mathrm{~Hz}, 2 \mathrm{H}), 3.03(\mathrm{t}, J=5.9 \mathrm{~Hz}, 2 \mathrm{H}), 2.04-1.95(\mathrm{~m}, 2 \mathrm{H}), 1.18(\mathrm{t}, J=7.1 \mathrm{~Hz}, 3 \mathrm{H})$. Exchangeable protons not observed. LCMS (Method A) $\mathrm{m} / \mathrm{z} 945.7(\mathrm{M}+\mathrm{H})^{+} \mathrm{Rt} 1.45 \mathrm{~min}$ (>95\% pure).

iii. 2-(8-(Benzo[d]thiazol-2-ylcarbamoyl)-3,4-dihydroisoquinolin-2(1H)-yl)-5-(3-(4-((S)24-((2S,4R)-4-hydroxy-2-((4-(4-methylthiazol-5-yl)benzyl)carbamoyl)pyrrolidine-1carbonyl)-25,25-dimethyl-22-oxo-4,7,10,13,16,19-hexaoxa-23-azahexacos-1-yn-1yl)phenoxy)propyl)thiazole-4-carboxylic acid (6)

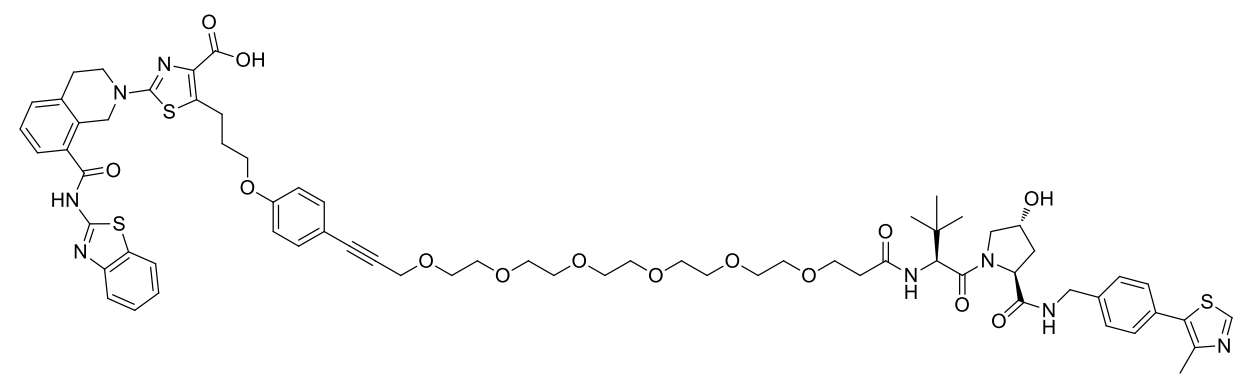

To a stirred solution of 22-(4-(3-(2-(8-(benzo[d]thiazol-2-ylcarbamoyl)-3,4-dihydroisoquinolin-2(1H)yl)-4-(ethoxycarbonyl)thiazol-5-yl)propoxy)phenyl)-4,7,10,13,16,19-hexaoxadocos-21-ynoic acid (48 $\mathrm{mg}, 0.051 \mathrm{mmol}),(2 S, 4 R)-1-((S)-2$-amino-3,3-dimethylbutanoyl)-4-hydroxy-N-(4-(4-methylthiazol-5yl)benzyl)pyrrolidine-2-carboxamide ( $24 \mathrm{mg}, 0.056 \mathrm{mmol}$ ) and DIPEA $(0.0270 \mathrm{~mL}, 0.152 \mathrm{mmol})$ in DMF 
$(0.5 \mathrm{~mL})$ was added HATU $(23 \mathrm{mg}, 0.061 \mathrm{mmol})$, then the mixture was stirred at $\mathrm{rt}$ for $16 \mathrm{~h}$. The mixture was diluted with $\mathrm{CH}_{2} \mathrm{Cl}_{2}(10 \mathrm{~mL})$ and water $(10 \mathrm{~mL})$, then the phases were separated using a hydrophobic frit. The aqueous layer was back-extracted with DCM $(10 \mathrm{~mL})$, then the organic layers were combined and concentrated under a stream of nitrogen. The residue was directly dissolved in $\mathrm{MeOH}(1 \mathrm{~mL}$ ), then $\mathrm{NaOH}$ ( $2 \mathrm{M}$ aq., $0.127 \mathrm{~mL}, 0.254 \mathrm{mmol}$ ) was added and the mixture stirred at 50 ${ }^{\circ} \mathrm{C}$ for $20 \mathrm{~h}$. The reaction mixture was directly purified by MDAP (ammonium bicarbonate modifier gradient) to give the required product ( $17.5 \mathrm{mg}, 26 \%$ yield over two steps) as a white solid.

${ }^{1} \mathrm{H}$ NMR $\left(400 \mathrm{MHz}\right.$, DMSO- $\left.d_{6}\right) \delta 8.97(\mathrm{~s}, 1 \mathrm{H}), 8.53(\mathrm{t}, J=5.9 \mathrm{~Hz}, 1 \mathrm{H}), 8.01(\mathrm{~d}, J=7.8 \mathrm{~Hz}, 1 \mathrm{H}), 7.88(\mathrm{~d}, J=$ $9.5 \mathrm{~Hz}, 1 \mathrm{H}), 7.77(\mathrm{~d}, J=8.1 \mathrm{~Hz}, 1 \mathrm{H}), 7.68(\mathrm{~d}, J=7.3 \mathrm{~Hz}, 1 \mathrm{H}), 7.50-7.29(\mathrm{~m}, 10 \mathrm{H}), 6.89(\mathrm{~d}, J=8.8 \mathrm{~Hz}, 2 \mathrm{H})$, $4.84(\mathrm{~s}, 2 \mathrm{H}), 4.55(\mathrm{~d}, J=9.3 \mathrm{~Hz}, 1 \mathrm{H}), 4.48-4.38(\mathrm{~m}, 2 \mathrm{H}), 4.35(\mathrm{~s}, 3 \mathrm{H}), 4.22(\mathrm{dd}, J=5.4,15.9 \mathrm{~Hz}, 1 \mathrm{H}), 3.99$ $(\mathrm{t}, J=6.2 \mathrm{~Hz}, 2 \mathrm{H}), 3.74-3.44(\mathrm{~m}, 28 \mathrm{H}), 3.16(\mathrm{t}, J=7.6 \mathrm{~Hz}, 2 \mathrm{H}), 3.02(\mathrm{t}, J=5.7 \mathrm{~Hz}, 2 \mathrm{H}), 2.44(\mathrm{~s}, 3 \mathrm{H}), 2.40-$ $2.29(\mathrm{~m}, 1 \mathrm{H}), 2.08-1.95(\mathrm{~m}, 3 \mathrm{H}), 1.94-1.84(\mathrm{~m}, 1 \mathrm{H}), 0.93(\mathrm{~s}, 9 \mathrm{H})$. Acid and amidobenzothiazole protons not observed. LCMS (Method B) $\mathrm{m} / \mathrm{z} 665.6([\mathrm{M}+2 \mathrm{H}] / 2)^{+} \mathrm{Rt} 0.98 \mathrm{~min}$ (>95\% pure). HRMS (ES) calcd for $\mathrm{C}_{68} \mathrm{H}_{81} \mathrm{~N}_{8} \mathrm{O}_{14} \mathrm{~S}_{3}(\mathrm{M}+\mathrm{H})^{+} 1329.5034$ found 1329.5017 .

iv. 2-(8-(Benzo[d]thiazol-2-ylcarbamoyl)-3,4-dihydroisoquinolin-2(1H)-yl)-5-(3-(4-((R)24-((2R,4S)-4-hydroxy-2-((4-(4-methylthiazol-5-yl)benzyl)carbamoyl)pyrrolidine-1carbonyl)-25,25-dimethyl-22-oxo-4,7,10,13,16,19-hexaoxa-23-azahexacos-1-yn-1yl)phenoxy)propyl)thiazole-4-carboxylic acid (7)

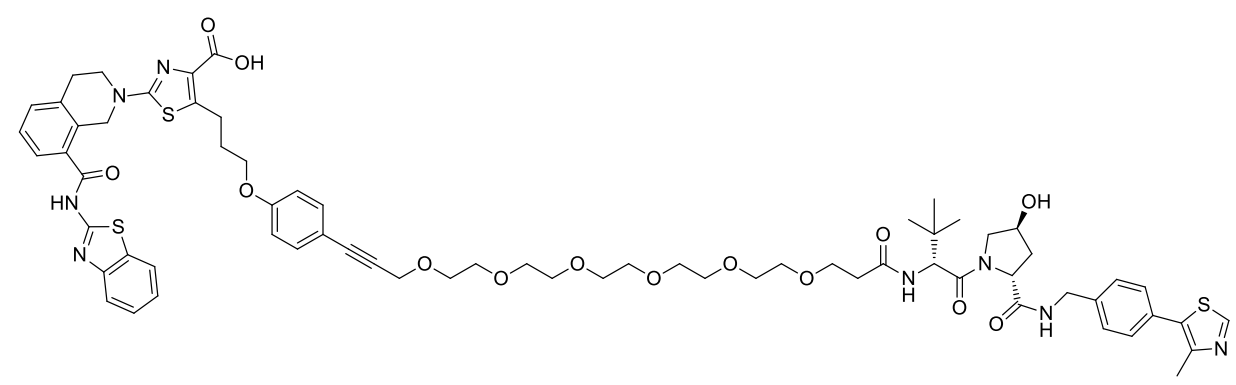

To a stirred solution of 22-(4-(3-(2-(8-(benzo[d] thiazol-2-ylcarbamoyl)-3,4-dihydroisoquinolin-2(1H)yl)-4-(ethoxycarbonyl)thiazol-5-yl)propoxy)phenyl)-4,7,10,13,16,19-hexaoxadocos-21-ynoic acid (47 $\mathrm{mg}, 0.050 \mathrm{mmol}),(2 R, 4 S)-1-((R)-2$-amino-3,3-dimethylbutanoyl)-4-hydroxy- $N$-(4-(4-methylthiazol-5yl)benzyl)pyrrolidine-2-carboxamide $(24 \mathrm{mg}, 0.055 \mathrm{mmol}$ ) and DIPEA $(0.026 \mathrm{~mL}, 0.15 \mathrm{mmol})$ in DMF $(0.5 \mathrm{~mL})$ was added HATU $(21 \mathrm{mg}, 0.055 \mathrm{mmol})$, then the mixture was stirred at rt for $16 \mathrm{~h}$. The mixture was diluted with $\mathrm{CH}_{2} \mathrm{Cl}_{2}(10 \mathrm{~mL})$ and water $(10 \mathrm{~mL})$, then the phases were separated using a hydrophobic frit. The aqueous layer was back-extracted with $D C M(10 \mathrm{~mL})$, then the organic layers were combined and concentrated under a stream of nitrogen. The residue was directly dissolved in Methanol ( $1 \mathrm{~mL}$ ), then sodium hydroxide ( $2 \mathrm{M}$ aq., $0.124 \mathrm{~mL}, 0.249 \mathrm{mmol}$ ) was added and the mixture stirred at $50^{\circ} \mathrm{C}$ for $20 \mathrm{~h}$. The reaction mixture was directly purified by MDAP (ammonium bicarbonate modifier gradient) to give the required product ( $31.4 \mathrm{mg}, 48 \%$ yield over two steps) as a white solid.

1H NMR (400 MHz, DMSO- $\left.d_{6}\right) \delta 8.97(\mathrm{~s}, 1 \mathrm{H}), 8.53(\mathrm{t}, J=6.0 \mathrm{~Hz}, 1 \mathrm{H}), 8.02(\mathrm{~d}, J=7.6 \mathrm{~Hz}, 1 \mathrm{H}), 7.87(\mathrm{~d}, J$ $=9.3 \mathrm{~Hz}, 1 \mathrm{H}), 7.78(\mathrm{~d}, J=7.8 \mathrm{~Hz}, 1 \mathrm{H}), 7.67(\mathrm{~d}, J=7.1 \mathrm{~Hz}, 1 \mathrm{H}), 7.50-7.31(\mathrm{~m}, 10 \mathrm{H}), 6.89(\mathrm{~d}, J=8.8 \mathrm{~Hz}$, $2 \mathrm{H}), 4.83(\mathrm{~s}, 2 \mathrm{H}), 4.55(\mathrm{~d}, J=9.3 \mathrm{~Hz}, 1 \mathrm{H}), 4.47-4.38(\mathrm{~m}, 2 \mathrm{H}), 4.35(\mathrm{~s}, 3 \mathrm{H}), 4.22(\mathrm{dd}, J=5.5,16.0 \mathrm{~Hz}$, $1 \mathrm{H}), 3.99(\mathrm{t}, J=6.2 \mathrm{~Hz}, 2 \mathrm{H}), 3.75-3.44(\mathrm{~m}, 28 \mathrm{H}), 3.16(\mathrm{t}, J=7.5 \mathrm{~Hz}, 2 \mathrm{H}), 3.02(\mathrm{t}, J=5.9 \mathrm{~Hz}, 2 \mathrm{H}), 2.44(\mathrm{~s}$, $3 \mathrm{H}), 2.39-2.30(\mathrm{~m}, 1 \mathrm{H}), 2.00(\mathrm{dd}, J=7.9,12.8 \mathrm{~Hz}, 3 \mathrm{H}), 1.94-1.85(\mathrm{~m}, 1 \mathrm{H}), 0.93(\mathrm{~s}, 9 \mathrm{H})$. Acid and 
amidobenzothiazole protons not observed. LCMS (Method B) m/z $665.7([\mathrm{M}+2 \mathrm{H}] / 2)^{+} \mathrm{Rt} 0.98 \mathrm{~min}$ (>95\% pure). HRMS (ES) calcd for $\mathrm{C}_{68} \mathrm{H}_{81} \mathrm{~N}_{8} \mathrm{O}_{14} \mathrm{~S}_{3}([\mathrm{M}+2 \mathrm{H}] / 2)^{+} 655.2556$ found 665.2553 .

\section{Protein production}

\section{a. Purification of ElonginB:ElonginC:VHL complex}

Based on the trimeric structure of EloginB/EloginC/VHL reported by Stebbins, et al ${ }^{4}$. VHL(E55-D213) domain was cloned into $\mathrm{pET30}$ a vector and Elongin $\mathrm{B}(\mathrm{M} 1-\mathrm{Q} 118)$, Elongin $\mathrm{C}(\mathrm{M} 17-\mathrm{C} 112)$ construct was cloned into pCDFDuet1 vector. The human VHL with N-terminal His6 tag with a TEV protease cleavage site was co-expressed with Elongin $B$ and ELongin $C$ in E. coli. The recombinant DNAs from VHL \& Elongin B, C were transformed into BL21(DE3) Gold competent cells. BL21(DE3) were grown at $37^{\circ} \mathrm{C}$ to an absorbance of 0.4-0.5 (OD600) in LB media and then transferred to $25^{\circ} \mathrm{C}$ induction with $0.1 \mathrm{mM}$ IPTG at an absorbance of 0.6-0.8 (OD600). Cells were harvested 16 hours post induction and the pellet was resuspended and sonicated in a buffer containing $50 \mathrm{mM}$ Tris, $\mathrm{pH} 7.5,300 \mathrm{mM} \mathrm{NaCl}, 1 \mathrm{mM}$ DTT and EDTA-free protease inhibitor tablets (Roche). Cell lysates were loaded onto a nickel column (Qiagen) in a buffer containing $50 \mathrm{mM}$ Tris, $\mathrm{pH} 7.5,300 \mathrm{mM} \mathrm{NaCl}, 1 \mathrm{mM}$ DTT and eluted with $250 \mathrm{mM}$ Imidazole in the same buffer; the elution was digested by $\operatorname{TEV}(1: 40)$ and dialyzed in a buffer containing $50 \mathrm{mM}$ Tris, pH7.5, 300mM NaCl , $1 \mathrm{mM} \mathrm{DTT}$, then the protein was loaded onto nickel column again (Qiagen) and pooled together the target protein. The protein was then loaded onto a $5 \mathrm{~mL} \mathrm{Q} \mathrm{HP} \mathrm{column} \mathrm{(GE}$ Healthcare) in a buffer $25 \mathrm{mM}$ Tris, $1 \mathrm{mM}$ TCEP, pH7.5 and eluted at $0 \mathrm{mM} \mathrm{NaCl}$ with a linear gradient of the same buffer and $1.0 \mathrm{M} \mathrm{NaCl}$. The protein was further purified on a size-exclusion Superdex 75 column (GE Healthcare) in a buffer containing $50 \mathrm{mM}$ Tris, $300 \mathrm{mM} \mathrm{NaCl}, 1 \mathrm{mM}$ DTT, pH 7.5. Fractions containing ElonginB:ElonginC:VHL complex were pooled and concentrated to $20 \mathrm{mg} / \mathrm{ml}$ for store at $80^{\circ} \mathrm{C}$

\section{b. Purification of $\mathrm{BCl}-\mathrm{xL}$}

Human $\mathrm{Bcl}$-xL(MSMA-1-209) was cloned into $\mathrm{pET} 21 \mathrm{~b}$ vector with C-terminal His6 tag. The recombinant DNAs of Bcl-xL were transformed into BL21(DE3) Gold competent cells. cells were grown at $37^{\circ} \mathrm{C}$ to an absorbance of 0.4 (OD600) in LB media and then transferred to $16^{\circ} \mathrm{C}$ induction with $0.1 \mathrm{mM}$ IPTG at an absorbance of 0.8 (OD600). Cells were harvested 16 hours post induction and the pellet was resuspended and sonicated in a buffer containing $20 \mathrm{mM}$ Hepes, $\mathrm{pH} 7.0,300 \mathrm{mMKCl}, 5 \% \mathrm{Glycerol}$ and EDTA-free protease inhibitor tablets (Roche). Cell lysates were loaded onto a nickel column (Qiagen) in a buffer containing $20 \mathrm{mM}$ Hepes, $\mathrm{pH} 7.0,300 \mathrm{mM} \mathrm{KCl}, 5 \% \mathrm{Glycerol}$ and eluted with $250 \mathrm{mM}$ imidazole in the same buffer; the elution was then loaded onto a $5 \mathrm{~mL}$ Q-FF column (GE Healthcare) in a buffer $220 \mathrm{mMHepes}, \mathrm{pH} 7.0,10 \%$ glycerol and eluted at $0 \mathrm{mM} \mathrm{NaCl}$ with a linear gradient of the same buffer and $1.0 \mathrm{MNaCl}$. The protein was further purified on a size-exclusion Superdex 200 column (GE Healthcare) in a buffer containing $25 \mathrm{mM}$ Tris, $300 \mathrm{mM} \mathrm{NaCl}, 1 \mathrm{mM} \mathrm{DTT}$, pH 7.5. Fractions containing $\mathrm{Bcl}-\mathrm{xL}$ protein were pooled and concentrated to $10 \mathrm{mg} / \mathrm{mL}$ for storage at $-80^{\circ} \mathrm{C}$.

\section{Biochemical, Cellular and Biophysics methods}

\section{a. HTRF-Assay}

Fluorescently labelled Bad peptide binding to Bcl-xL was monitored by HTRF between anti-GST-Tb and FAM-Bad peptide using GST-Tag Bcl-xL proteins. The final assay condition are $3 \mathrm{nM} \mathrm{Bcl-xL}$ and $40 \mathrm{nM}$ FAM-Bad peptide in $20 \mathrm{mM}$ potassium phosphate, $\mathrm{pH} 7.5,50 \mathrm{mM} \mathrm{NaCl}, 1 \mathrm{mM}$ EDTA, $0.005 \%$ NP-40 with compounds tested as 10 point dose responses from 3-fold serial dilution starting at $10 \mu \mathrm{M}$. Compounds 
in DMSO were added to $\mathrm{Bcl}-\mathrm{xL}$ solution, incubated for $10 \mathrm{~min}$ at room temperature, followed by addition of the FAM-Bad peptide and another 10 min incubation. Finally, Anti-GST-Tb was added and the signal was measured after $60 \mathrm{~min}$ incubation. Data was obtained in duplicate and fitted to the equation : Y=Top-(Top-Bottom)/(1+(X/EC50)^HillSlope).

For the VHL-based Bcl-xL PROTAC pair 6 and 7, the measured $\mathrm{EC}_{50}$ values for $\mathrm{Bcl}-\mathrm{xL}$ binding are $0.46 \mathrm{nM}$ and $0.58 \mathrm{nM}$ respectively. The binding affinity for their parental $\mathrm{Bcl}-\mathrm{xL}$ binding warhead is $\sim 0.9 \mathrm{nM}$. The binding affinity is so tight for the $\mathrm{Bcl}-\mathrm{xL}$ inhibitor or PROTAC that the fitted $\mathrm{EC}_{50}$ value only gives an upper limit estimated the actual value. This is also reflected by the large value of the fitted hill coefficients, which are typically between 1.5-3. The binding affinity of the VHL warhead to VHL is 300nM (C. Crews et al; Angew. Chem. Int. Ed. 2012, 51, 11463-11467; Crews \& GSK, ACS Chem. Biol., 2015, 10, 1831-1837) and the binding affinity of PROTAC 6 to $\mathrm{VHL}$ is $\sim 3.2 \mu \mathrm{M}$.

This assay was carried out at RBC.

\section{b. Bcl-xL protein quantification by western blotting}

THP-1 cells were resuspended in media containing the indicated concentrations of Compounds 5-7, and incubated $37^{\circ} \mathrm{C}$ and $5 \% \mathrm{CO} 2$ for dedicated hours. After treatment, cells were harvested, washed twice in PBS and lysed in $50 \mu \mathrm{l}$ cell lytic buffer (M-PER mammalian protein extraction reagent, Thermo), containing protease inhibitor cocktail (Halt Protease Inhibitor Cocktail, EDTA-Free, Thermo). The clear supernatant was collected after cell debris was removed by centrifugation at $14000 \mathrm{~g}$ for 15 minutes. Cell lysate was subjected to protein quantification by BCA protein assay kit (MERCK) according to the manufacture's instruction. $20 \mu \mathrm{g}$ total protein (or desired protein amount) were used per sample. BclxL (54H6) Rabbit mAb (1:2000, Cell Signaling), and $\beta$-actin Antibody (1:5000, Cell Signaling) were used to probe the target protein, $\mathrm{Bcl}-\mathrm{xL}$ and $\beta$-actin. The exposure signal was captured by imaging system (ChemiDoc ${ }^{\mathrm{TM}}$ XRS+ System, Bio-Rad Image Lab). Bcl-xL expression was shown as \% normalized Bcl-xL using the calculation of $\mathrm{Bcl}-\mathrm{xL}$ signal divided by beta-actin signal analyzed by image J. Data for two replicates are shown. $\mathrm{DC}_{50}$ and $\mathrm{D}_{\mathrm{Max}}$ degradation were calculated using GraphPad Prism software and equation: $\mathrm{Y}=$ Top-(Top-Bottom) $/\left(1+(\mathrm{X} / \mathrm{DC} 50)^{\wedge}\right.$ HillSlope). For the analysis the highest two concentrations for PROTAC 6 and 7 were excluded due to the presence of the hook effect being apparent.

\section{c. Surface Plasmon Resonance affinity measurements}

Affinity of compounds were determined by SPR using equilibrium concentration titrations on a Biacore T200 Instrument (GE Healthcare) at $25^{\circ} \mathrm{C}$. The VBC ternary complex VHL (53-213)/ Elongin B(1-118)/ Elongin $\mathrm{C}(17-112)$ was immobilised using $75-150 \mu \mathrm{g} / \mathrm{mL}$ in $10 \mathrm{mM} \mathrm{NaOAc} \mathrm{pH} 5.5$ on three flow cells at three immobilisation levels between $\sim 1 \mathrm{kRU}$ and $\sim 2 \mathrm{kRU}$, corresponding to injection times of $40 \mathrm{~s}, 50 \mathrm{~s}$ and 60s respectively. Compounds were prepared as concentrated DMSO stocks and 3-fold serially diluted in DMSO. This dilution series was further diluted 100-fold into HBS-EP+ (10mM HEPES, 150mM $\mathrm{NaCl}, 3 \mathrm{mM}$ EDTA, $0.01 \%$ Tween20), to give a final DMSO concentration of $1 \%$. Each titration series was injected across every flow-cell on the sensorchip for 60s for the control compound and 250s for the PROTAC samples at 30 $\mathrm{L} / \mathrm{min}$. Dissociation times 1000-2000s were used to ensure complete dissociation between injections. A series of DMSO injections in the range of $0.6-1.4 \%$ were used to correct for bulk shift effects, during reference subtraction.

A VHL binding control, was used to confirm the integrity of the VHL surface before and during each experiment. Eleven-point tripling dilution starting at $10 \mu \mathrm{M}$ were performed for all compounds tested. 
To determine the ternary complex affinities formed between VHL, PROTAC 6 and Bcl-xL, we established a pseudo binary titration of a commitant binary complex of Bcl-xL-PROTAC 6 at all concentrations of PROTAC 6 used. Eleven-point titrations of PROTAC 6 from a starting concentration of $5.5 \mu \mathrm{M}$ in the presence of $20 \mu \mathrm{M} \mathrm{Bcl}-\mathrm{xL}$. Assuming the affinity of PROTAC 6 for Bcl-xL is $1 \mathrm{nM}$ this corresponds to greater than $99.9 \%$ of PROTAC 6 being sequestered within a complex with Bcl-xL at all protein concentrations used (see below table).

\begin{tabular}{|c|c|c|c|c|}
\hline [Bcl-xL]tot (nM) & [PROTAC]tot (nM) & [Bcl-xL:PROTAC] (nM) & [PROTAC free] (nM) & \%PROTAC free \\
\hline 20000 & 0.056450293 & 0.05644747 & $2.82238 \mathrm{E}-06$ & 0.004999764 \\
\hline 20000 & 0.169350878 & 0.169342411 & $8.46719 \mathrm{E}-06$ & 0.004999792 \\
\hline 20000 & 0.508052634 & 0.508027232 & $2.5402 \mathrm{E}-05$ & 0.004999877 \\
\hline 20000 & 1.524157903 & 1.524081693 & $7.62099 \mathrm{E}-05$ & 0.005000131 \\
\hline 20000 & 4.572473708 & 4.572245044 & 0.000228665 & 0.005000893 \\
\hline 20000 & 13.71742112 & 13.71673482 & 0.000686307 & 0.005003181 \\
\hline 20000 & 41.15226337 & 41.15020162 & 0.002061752 & 0.005010058 \\
\hline 20000 & 123.4567901 & 123.4505793 & 0.006210866 & 0.005030801 \\
\hline 20000 & 370.3703704 & 370.3515034 & 0.018866945 & 0.005094075 \\
\hline 20000 & 1111.111111 & 1111.052291 & 0.058820232 & 0.005293821 \\
\hline 20000 & 3333.333333 & 3333.133348 & 0.199985601 & 0.005999568 \\
\hline 20000 & 10000 & 9999.0002 & 0.99980006 & 0.009998001 \\
\hline
\end{tabular}

*Assuming $\mathrm{K}_{\mathrm{D}}$ PROTAC 6 for $\mathrm{BCl}-\mathrm{xL}$ is $1 \mathrm{nM}$

Ten-point titrations of PROTAC 7 from a starting concentration of $10 \mu \mathrm{M}$ were performed. No specific binding was observed to $\mathrm{VHL}$, resulting in a KD estimate of $>5 \mu \mathrm{M}$.

The results of 3 technical replicates for each of 2 experimental replicates, i.e. new independent titrations from different stock and separate immobilisation surface is presented below.

\begin{tabular}{|c|c|c|}
\hline Compound & $K_{D}(n=6)$ in $n M$ & Stdev \\
\hline VHL control & 130 & 26 \\
\hline PROTAC 6 & 190 & 84 \\
\hline PROTAC $6+20 \mu \mathrm{M}$ Bcl-xL & 290 & 140 \\
\hline Alpha ratio & 0.72 & 0.16 \\
\hline PROTAC $7^{\#}$ & $>5000$ & / \\
\hline
\end{tabular}

\# Triplicate experiments of single concentration injections of $20 \mu \mathrm{M} \mathrm{Bcl}-\mathrm{xL}$ in the presence and absence of $5.5 \mu \mathrm{M}$ PROTAC7 also resulted in no specific binding observed. A titration was not performed in this case.

All data fitting was performed within the Bia-evaluation software. Sensorgrams were doubly subtracted, including a bulkshift correction during reference subtraction. The concentration response data was then fitted using non-linear least-squares regression to a Langmuir binding isotherm. 


\section{d. Effect of PROTAC 6 and 7 on MOLT-4 Cells}

\section{Caspase $3 / 7$ activity in MOLT-4 cells}

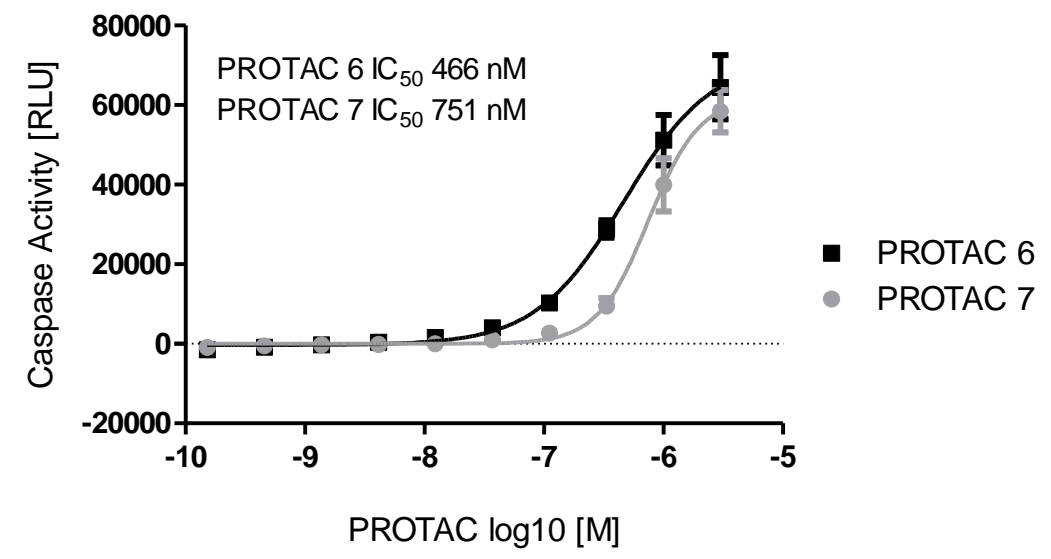

MOLT-4 Cell Viability

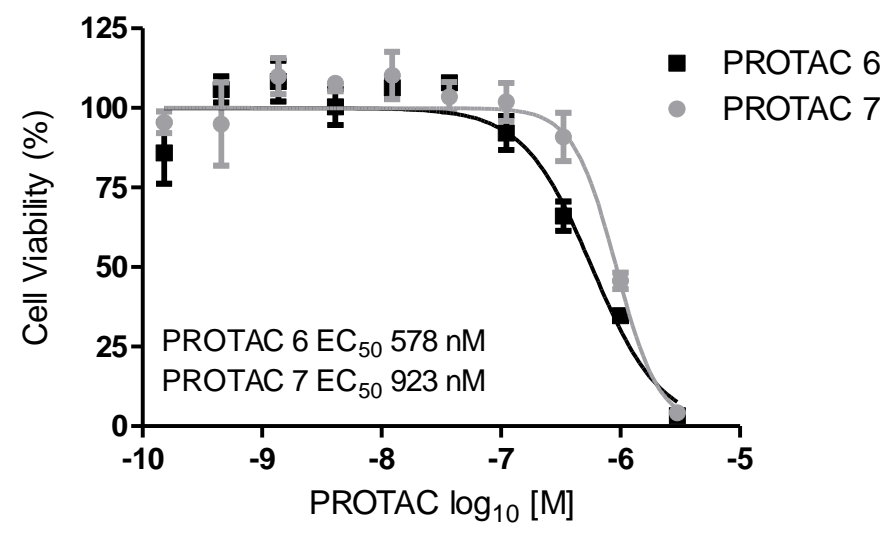

\section{CTG viability assay}

3,000 cells were used for each sample. Cells were resuspended in Complete 1640 medium containing indicated concentrations of compounds 6 and 7 or vehicle and incubated at $37^{\circ} \mathrm{C}$ and $5 \% \mathrm{CO} 2$ for 8 hours. After 8 hours of incubation, $100 \mu \mathrm{L}$ of CellTiter-Glo ${ }^{\circledR}$ Luminescent Cell Viability Assay Reagent (Promega) was added to each well before gently mixing contents of wells using a plate shaker at 300$500 \mathrm{rpm}$ for 30 seconds. After incubation at room temperature for 1 hour, the luminescence of each sample in a plate-reading luminometer was measured (FlexStation 3 Multi-Mode Microplate Reader, Molecular Devices). Final luminescence was normalized to the average luminescence in the no-drug wells (100\% viability) and IC50 was then calculated using GraphPad Prism software.

\section{Caspase assay}

3,000 cells were used for each sample. Cells were resuspended in Complete 1640 medium containing indicated concentrations of compounds 6 and 7 or vehicle and incubated at $37^{\circ} \mathrm{C}$ and $5 \% \mathrm{CO} 2$ for 8 
hours. $100 \mu \mathrm{L}$ of Caspase-Glo ${ }^{\circledR}$ 3/7 Assay Reagent (Promega) was added to each well before gently mixing contents of wells using a plate shaker at 300-500rpm for 30 seconds. After incubation at room temperature for 1 hour, luminescence of each sample was measured in a plate-reading luminometer (FlexStation 3 Multi-Mode Microplate Reader, Molecular Devices). Final luminescence had the average luminescence from the no-drug wells (no Caspase 3/7 expression) subtracted, and raw counts were plotted. EC50 was then calculated using GraphPad Prism software.

\section{Crystallography}

\section{a. Purification of the ElonginB:ElonginC:VHL/PROTAC 6/Bcl-xL complex}

PROTAC 6 was added into Bcl-xL and incubated for 4 hours, before ElonginB:ElonginC:VHL was added to this mixture and incubated overnight. A molar ratio of PROTAC $6: \mathrm{Bcl}-\mathrm{xL}$ : ElonginB:ElonginC:VHL of 1:1:1 was used. The liganded heterotetramer was purified on a Superdex 200 column (GE Healthcare) in $25 \mathrm{mM}$ Tris, $300 \mathrm{mM} \mathrm{NaCl}, 1 \mathrm{mM}$ DTT, pH 7.5. Fractions containing the heterotetramer were pooled and concentrated to $22 \mathrm{mg} / \mathrm{mL}$. (Protocols for production of the ElonginB:ElonginC: $\mathrm{VHL}$ complex and $\mathrm{Bcl}-\mathrm{xL}$ protein are described in the protein production section of the supplementary methods)

\section{b. Crystallization of the ElonginB:ElonginC:VHL/PROTAC 6/Bcl-xL complex}

Crystallization screening of the ElonginB:ElonginC:VHL/PROTAC 6/Bcl-xL complex was carried using a NT8 crystallization robot. Diffraction quality crystals were grown at $18^{\circ} \mathrm{C}$ from $1.0 \mu \mathrm{L}+1.0 \mu \mathrm{L}$ vapor diffusion hanging drops at $22 \mathrm{mg} / \mathrm{mL}$ in $0.2 \mathrm{M}$ potassium iodide, $0.1 \mathrm{M} \mathrm{MES} \mathrm{pH} \mathrm{6.5,} \mathrm{20-25 \%} \mathrm{PEG} 4000$. Large crystals appeared after 3-5 days.

\section{c. Structure determination of the ElonginB:ElonginC:VHL/PROTAC 6/Bcl-xL complex}

Diffraction data was collected at CLS beam line 08ID- 1 and processed to $1.92 \AA$ in the $P 2{ }_{1}{ }_{1} 2_{1}$ space group using $\mathrm{XDS}^{5}$. A single copy of the complex heterotetramer was located in the asymmetric unit using Phaser $^{6}$ using search models of a pVHL-ElonginB-ElonginC complex (PDB: 1LM8) and the structure of human Bcl-xL (PDB: 1MAZ). Initial refinement using Refmac5 ${ }^{7}$ of the CCP4 package ${ }^{8}$, revealed a sizable stretch of difference between $\mathrm{VHL}$ and $\mathrm{BCl}-\mathrm{xL}$ easily fitted as the compound PROTAC 6. Iterative cycles of model building by hand using Coot. ${ }^{9}$ Refmac refinement before validation using molprobility and mogul completed the structure determination process. Diffraction quality, refinement, and structure statistics are given in Table of data collection and refinement statistics.

\section{d. Table of Data collection and refinement statistics}

Data collection on a single crystal

\begin{tabular}{|c|c|}
\hline Wavelength(Å) & 1.03320 \\
\hline Space group & $\mathrm{P} 2{ }_{1} 2_{1} 2_{1}$ \\
\hline \multicolumn{2}{|l|}{ Cell parameters } \\
\hline$a, b, c(\AA)$ & $70.99,101.18,106.93$ \\
\hline$\alpha, \beta, v\left(^{\circ}\right)$ & $90.00,90.00,90.00$ \\
\hline Resolution(Å) & $47.27-1.92(1.97-1.92)$ \\
\hline Observed reflections & 387092 (22297) \\
\hline Unique reflections & 59379 (3945) \\
\hline
\end{tabular}




\begin{tabular}{ll}
\hline Average redundancy & $6.5(5.7)$ \\
Average $\mathbf{I} \sigma\left(\mathbf{I}^{\prime}\right.$ & $15.1(2.5)$ \\
Completeness (\%) & $99.9(99.6)$ \\
Rmerge (\%) & $7.9(63.8)$ \\
& \\
Refinement and structure model & \\
Reflections & \\
Working set & 56468 \\
Test set & 2910 \\
R-factor/Free R-factor & $0.1694 / 0.1957$ \\
No. atoms & 4810 \\
Protein & 4115 \\
Ligand/ion & $93 / 139$ \\
Water & 463 \\
Average B factor(Åv) & \\
All atoms & 36.22 \\
Protein & 34.76 \\
Ligand/lon & $28.94 / 57.71$ \\
Water & 44.20 \\
RMS deviations & \\
Bond lengths(Å) & 0.0041 \\
Bond angles( ${ }^{\circ}$ ) & 1.2520 \\
Ramachandran plot(\%) & \\
Favored regions(\%) & 97.42 \\
Outliers regions(\%) & 0.23 \\
\hline
\end{tabular}

* Highest resolution shell is shown in parenthesis

\section{e. Electron density maps around PROTAC 6}

Different views shown of electron density around PROTAC 6.

\begin{tabular}{|c|c|c|}
\hline OMIT (Fo-Fc)map & OMIT (2Fo-Fc) \\
contoured at \pm 3.0 sigma (blue/red) & contoured at +1.0 sigma (blue) \\
Within the Bcl-xL binding site & Within the Bcl-xL binding site \\
\hline
\end{tabular}




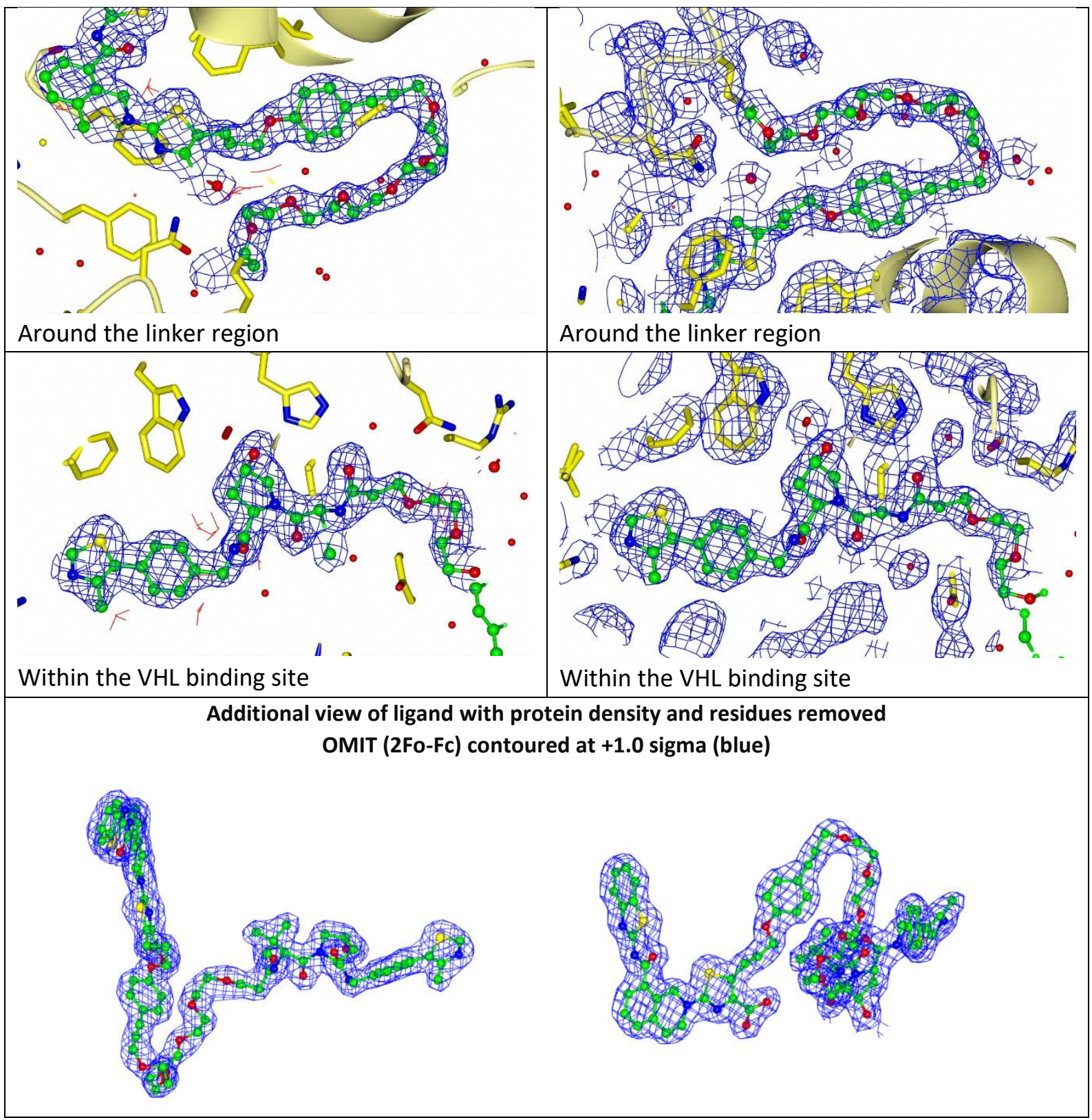

f. Comparison of $\mathrm{VHL}$ and $\mathrm{BCl}-\mathrm{xL}$ binding in binary and ternary complexes.

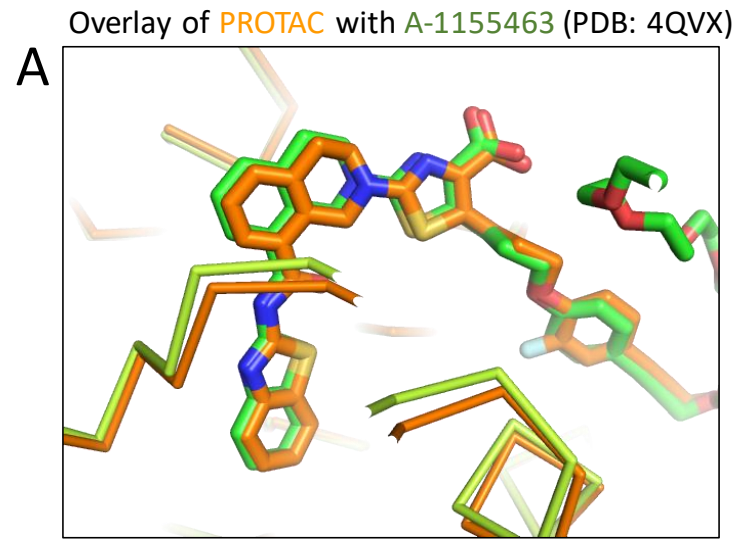
Overlay of PROTAC with VHL binder (PDB: 4W9H)

B

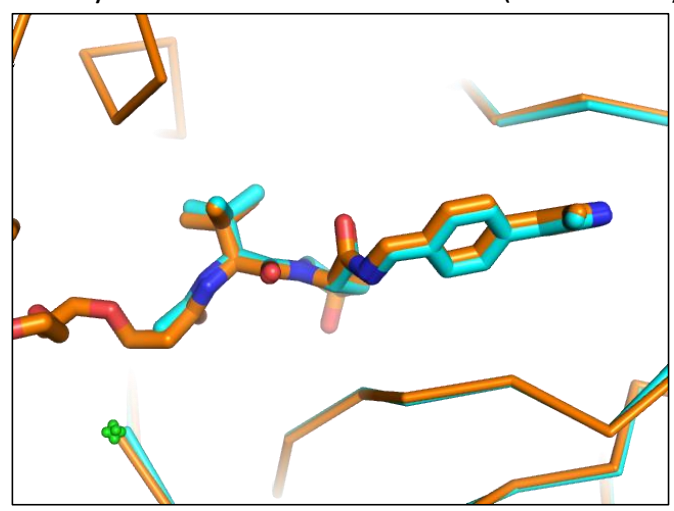

PROTAC ternary complex in orange. 
A: Overlay with binary structure of Bcl-xL with A-1155463 (PDB: 4QVX) shown in green.

B: Overlay with binary structure of Bcl-xL VHL binder (PDB: 4W9H) shown in cyan

No change in the binding mode are observed.

\section{g. Breakdown of buried surface areas in the ternary complexes ligase:ligand:target.}

Breakdown of buried surface areas in the ternary complexes ligase:ligand:target.

\begin{tabular}{|c|c|c|c|c|c|c|c|}
\hline $\begin{array}{l}\text { Buried surface } \\
\text { areas in ternary } \\
\text { complexes }\left(\AA^{2}\right)\end{array}$ & $\begin{array}{c}\text { VHL:PROTAC: } \\
\text { Bcl-xL }\end{array}$ & $\begin{array}{c}\text { VHL: MZ1: } \\
\text { Brd4 }\end{array}$ & $\begin{array}{l}\text { Bcl-xL with } \\
\text { A1155463 }\end{array}$ & $\begin{array}{c}\text { BRD4C } \\
\text { MS417 - } \\
\text { JQ1 like in } \\
\text { BRD4C }\end{array}$ & $\begin{array}{l}\text { VHL:PROTA } \\
\text { C:SMARCA }\end{array}$ & $\begin{array}{c}\text { CRBN: } \\
\text { lenalidomide: } \\
\text { CK1 } \alpha\end{array}$ & $\begin{array}{c}\text { CRBN: CC- } \\
\text { 885: } \\
\text { GSPT1 }\end{array}$ \\
\hline PDBCODE & & $5 T 35$ & $4 Q V X$ & 6DUV & $6 \mathrm{HR} 2$ & 5FQD & $5 \mathrm{HXB}$ \\
\hline Ligase:target PPIs & 676 & 688 & & & 649 & 1164 & 1263 \\
\hline Ligase:ligand & 911 & 957 & & & 9112 & 468 & 666 \\
\hline Target:ligand & 1536 & 976 & 1284 & 694.4 & 689 & 198 & 461 \\
\hline Total & 3123 & 2621 & & & 2250 & 1830 & 2390 \\
\hline
\end{tabular}

Total buried surface area $=$ ASA of one surface + second surface

Buried surface areas were calculated with PISA(Qt) (see ref. 52).

\section{h. Comparison of interface residues in ternary versus binary complexes}

Figure 3B + overlaid with Bxl-xL

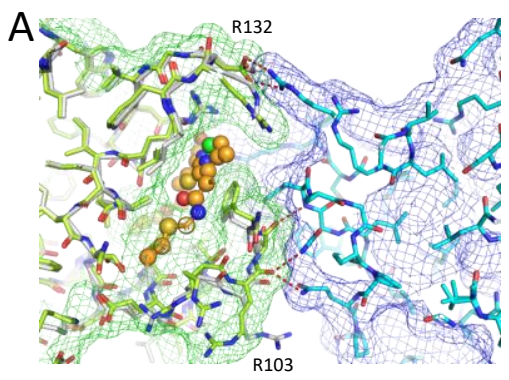

Figure 3B

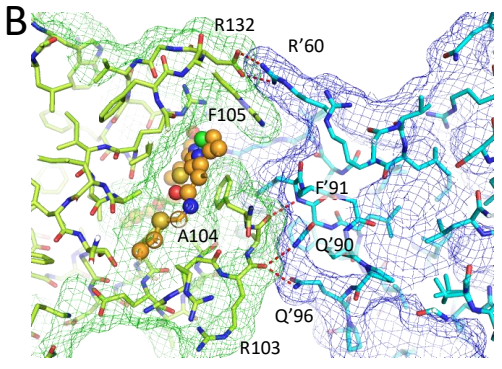

Figure 3B + overlaid with VHL

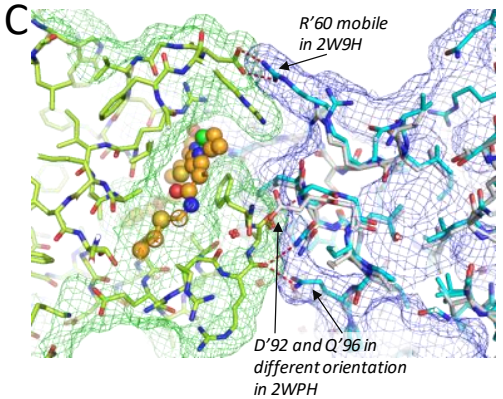

VHL (cyan), Bcl-xL (lime-green) and PROTAC 6 in multi-colored (orange, green, light-blue).

(A) Binary structure of Bcl-xL with A-1155463 (PDB: 4QVX) shown in white.

(B) Figure 3B

(C) Binary structure of VHL with bound ligand (PDB:4W9H) shown in white.

Changes in rotamers are seen in a few sidechains on edge of the Bcl-xL interface such as R132 and R103. Similarly, there are only a small number of alternative conformations in interface residues within VHL that can be observed such as D'92, Q'96. Additionally, $\mathrm{R}^{\prime} 60$ can be modelled in the ternary complex but is normally too mobile to be positioned for VHL alone. 
i. Binding of $\mathrm{VHL}$ in binding site of ternary complexes.

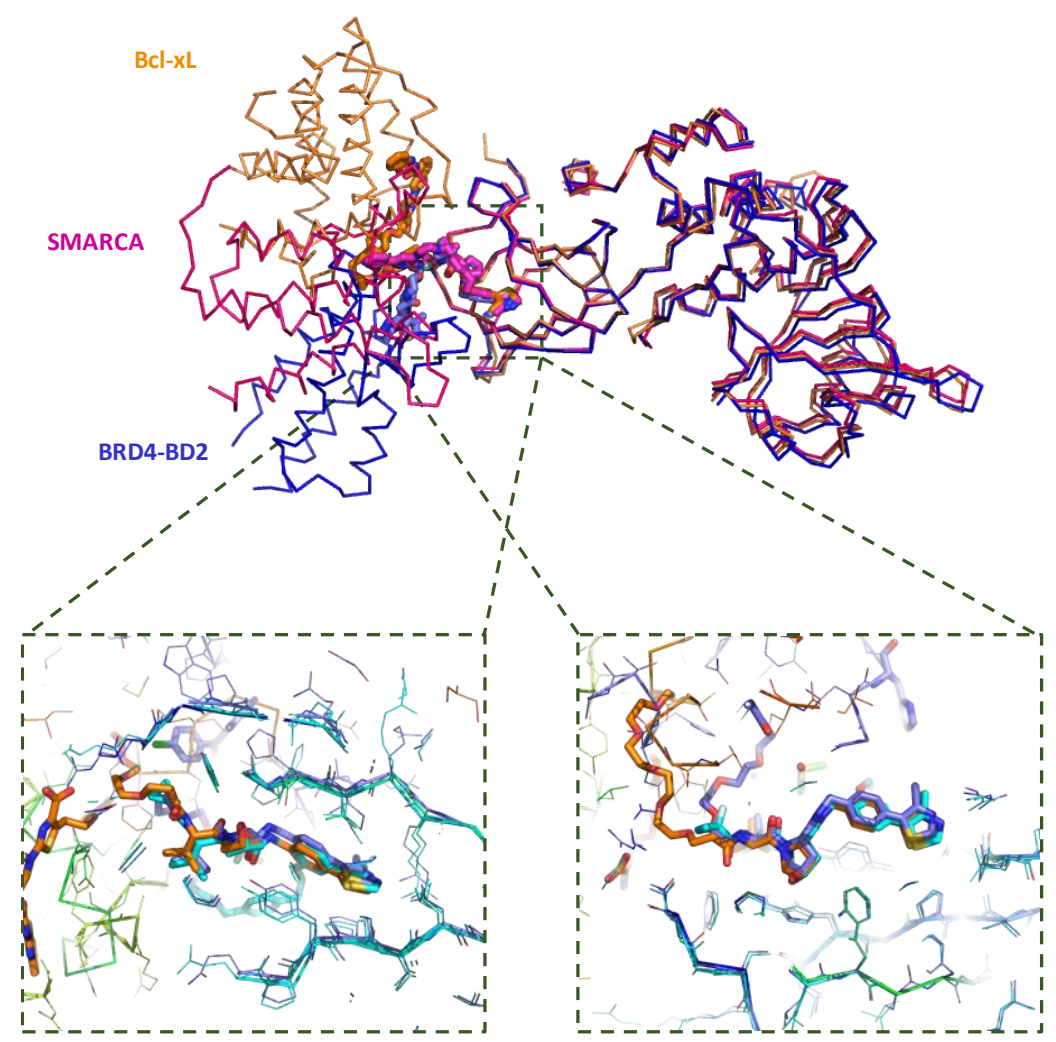

Figure 3C

Superimposition of VHL protein of the ternary complexes of ElonginB:ElonginC:VHL:PROTAC target protein complexes with Bcl-xL (orange) and BRD4-BD2 (blue), SMARCA2 (magenta). Two views of the common VHL binding motif within the VHL protein shown.

\section{j. Alignment of $\mathrm{Bcl}-2$ to consider the effect on the $\mathrm{Bcl}-\mathrm{xL} / \mathrm{VHL}$ interface.}
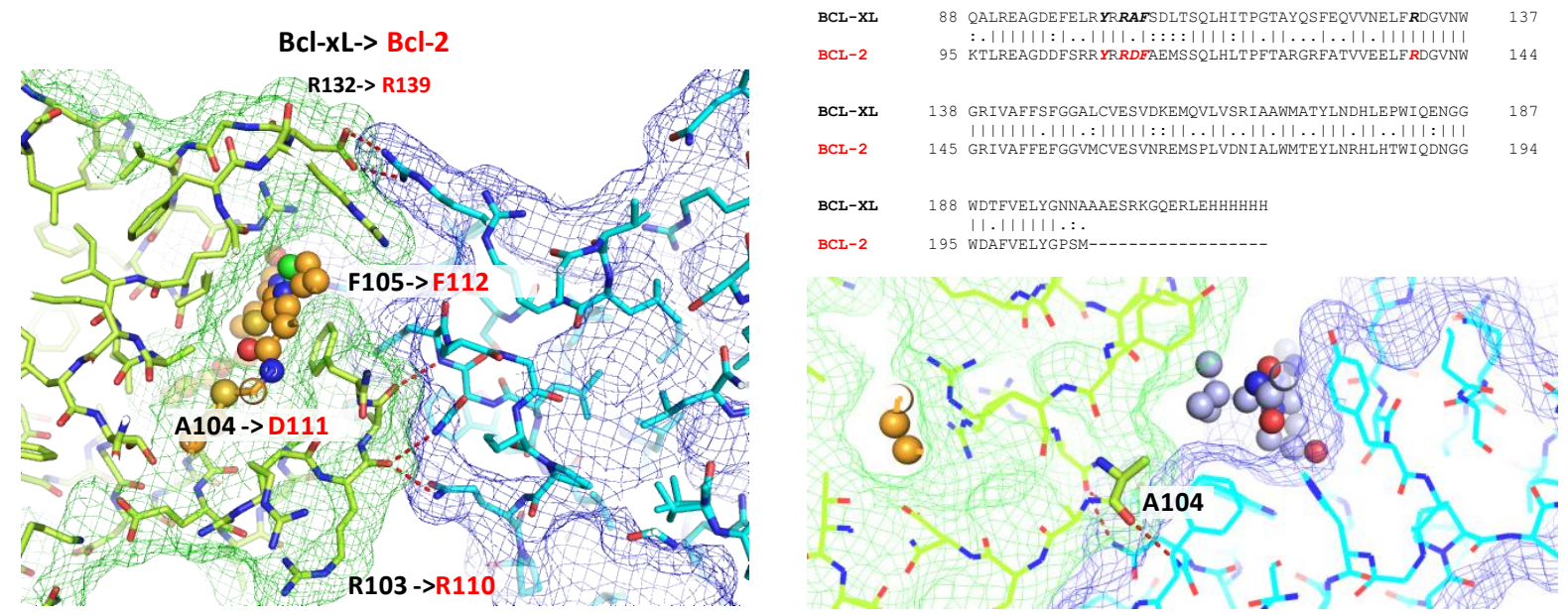

Figure 3B + Alignment of $\mathrm{Bcl}-\mathrm{xL}$ and $\mathrm{Bcl}-2$ with some key residues at the interface highlighted in red.

An alignment of $\mathrm{Bcl}-\mathrm{xL}$ with $\mathrm{Bcl}-2$ suggests many of the interfacial residues with $\mathrm{VHL}$ are conserve. BclxL residues Arg132, Phe105 and Arg103 are absolutely conserved in their Bcl-2 counterpart. However, 
the conservation is not complete. For example, Ala104 in Bcl-xL, would become Asp111 in Bcl-2. This replacement of a small hydrophobic residue with a larger charged residue would result in resulting in a steric clash with the t-Butyl of the VHL binder of PROTAC6 and repulsion effects as Ala104 sits in a tight hydrophobic pocket.

This suggests that PROTAC 6 could not prompt the formation of a similar ternary complex between $\mathrm{Bcl}-2$ and $\mathrm{VHL}$, as $\mathrm{A}-1155463$ has reduced affinity for $\mathrm{Bcl}-2$ compared to $\mathrm{Bcl}-\mathrm{xL}$ and the neo-protein interface between Bcl-2 and VHL would not be favorable in this particular ternary configuration.

\section{References}

1. Tao, Z. F., Hasvold, L., Wang, L., Wang, X., Petros, A. M., Park, C. H., Boghaert, E. R., Catron, N. D., Chen, J., Colman, P. M., Czabotar, P. E., Deshayes, K., Fairbrother, W. J., Flygare, J. A., Hymowitz, S. G., Jin, S., Judge, R. A., Koehler, M. F., Kovar, P. J., Lessene, G., Mitten, M. J., Ndubaku, C. O., Nimmer, P., Purkey, H. E., Oleksijew, A., Phillips, D. C., Sleebs, B. E., Smith, B. J., Smith, M. L., Tahir, S. K., Watson, K. G., Xiao, Y., Xue, J., Zhang, H., Zobel, K., Rosenberg, S. H., Tse, C., Leverson, J. D., Elmore, S. W., and Souers, A. J. (2014) Discovery of a Potent and Selective BCL-XL Inhibitor with in Vivo Activity, ACS Med Chem Lett 5, 1088-1093.

2. Galdeano, C., Gadd, M. S., Soares, P., Scaffidi, S., Van Molle, I., Birced, I., Hewitt, S., Dias, D. M., and Ciulli, A. (2014) Structure-guided design and optimization of small molecules targeting the protein-protein interaction between the von Hippel-Lindau (VHL) E3 ubiquitin ligase and the hypoxia inducible factor (HIF) alpha subunit with in vitro nanomolar affinities, J. Med. Chem. $57,8657-8663$.

3. Raina, K., Lu, J., Qian, Y., Altieri, M., Gordon, D., Rossi, A. M., Wang, J., Chen, X., Dong, H., Siu, K., Winkler, J. D., Crew, A. P., Crews, C. M., and Coleman, K. G. (2016) PROTAC-induced BET protein degradation as a therapy for castration-resistant prostate cancer, Proc. Natl. Acad. Sci. U. S. A. $113,7124-7129$.

4. Stebbins, C. E., Kaelin, W. G., Jr., and Pavletich, N. P. (1999) Structure of the VHL-ElonginC-ElonginB complex: implications for VHL tumor suppressor function, Science 284, 455-461.

5. Kabsch, W. (2010) Xds, Acta Crystallogr D Biol Crystallogr 66, 125-132.

6. McCoy, A. J., Grosse-Kunstleve, R. W., Adams, P. D., Winn, M. D., Storoni, L. C., and Read, R. J. (2007) Phaser crystallographic software, J Appl Crystallogr 40, 658-674.

7. Murshudov, G. N., Vagin, A. A., and Dodson, E. J. (1997) Refinement of macromolecular structures by the maximum-likelihood method, Acta Crystallogr D Biol Crystallogr 53, 240-255.

8. Collaborative Computational Project, N. (1994) The CCP4 suite: programs for protein crystallography, Acta Crystallogr D Biol Crystallogr 50, 760-763.

9. Emsley, P., and Cowtan, K. (2004) Coot: model-building tools for molecular graphics, Acta Crystallogr D Biol Crystallogr 60, 2126-2132.

10. Krissinel, E. (2015) Stock-based detection of protein oligomeric states in jsPISA, Nucleic Acids Res 43, W314-319. 